\title{
Studying the frequencies of the monthly middle-level cloud cover CM in Iraq.
}

\author{
1-Budoor Mohammed Dawood Al-Najjar \\ Elprincessa5@gmail.com \\ 2-Professor Dr. Ali A Kazem \\ Prof.dr.ali. alwaeli@ircoedu.uobaghdad.edu.iq \\ University of Baghdad / Ibn Rushd College of Education for Human Sciences / Department of Geography
}

\begin{abstract}
The concept of the research is based on the study of middle-level cloud cover, and its upper span reaches $6 \mathrm{~km}$, and it may exceed that up to $7 \mathrm{~km}$, as it may overlap slightly in the level of high clouds. In terms of frequency, the upper and lower limit for the period 1988-2018 and spatially for the nine types of middle-level clouds by choosing 13 climate monitoring stations distributed geographically. The study showed that the highest annual average monthly recurrence for the first type was recorded for the Diwaniyah station during April, the second type for the Mosul station in December, the third for Baghdad in December, the fourth type for the Diwaniyah station in November and the fifth in the Al-Hayy station in January, the sixth for the Baghdad station in October and the seventh for the Khalis station in March and the eighth station of Nasiriyah in November. As for the ninth type, it was found from the study that the stations did not record frequency of this type, as the annual rate of the monthly recurrence of its presence is almost non-existent for all stations.
\end{abstract}

Article Received: 10 August 2020, Revised: 25 October 2020, Accepted: 18 November 2020

\section{INTRODUCTION}

Clouds have an important effect on the climate because they are the source of rain and snow that reach the earth. They also affect solar and terrestrial radiation which determine the amount of penetration from the sun heat to the earth or from the earth heat to the upper atmosphere. Whether it is day or night, meteorological data and cloud cover are used in weather analysis which is very important for solar energy, air traffic management and weather forecasts.

\section{Research Objectives}

The aim of choosing the topic of the research is to study the nine types of middle-level clouds and their frequencies to determine the most and least frequent types and to know the minimum and highest levels during the months and seasons of the year in time and place, in addition to linking this to factors and causes, whether they are highlands and lows, pressure systems or natural and local factors.

\section{Research problem}

The problem is trying to answer the following question:

What are the types of middle-level clouds affecting Iraq and which type is the most frequent?

\section{Research hypothesis}

There is a variation in the frequency of the middlelevel cloud types affecting Iraq, in time and space.

\section{Research limits}

The spatial boundaries of the research are represented by the political borders of Iraq where 13 climate monitoring stations represented (Mosul, Kirkuk, Khalis, Baghdad, Hilla, Al-Hayy, Al-Rutba, Najaf, Diwaniyah, Samawah, Al-Amara, Nasiriyah, Basra) are chosen and studied, because they represent difference and disparity of the surface sections Iraq topographic (Map 1)

The temporal boundaries were represented by studying a major climate cycle (30 years) for the period 1988-2018, based on observational data for eight daily observations.

\section{Research method}

The research required some procedures, including the availability of data for middle-level clouds from the period 1988-2018 and processing them. They resulted in numerical tables and charts in graphic forms, using Microsoft Excel 2013. The monthly frequencies of middle-level clouds were extracted based on hourly observations and from the main tables for each of the stations classifying them in secondary tables for each of the nine types of middle-level clouds for all stations in the study area.

Map (1) of the study area stations 


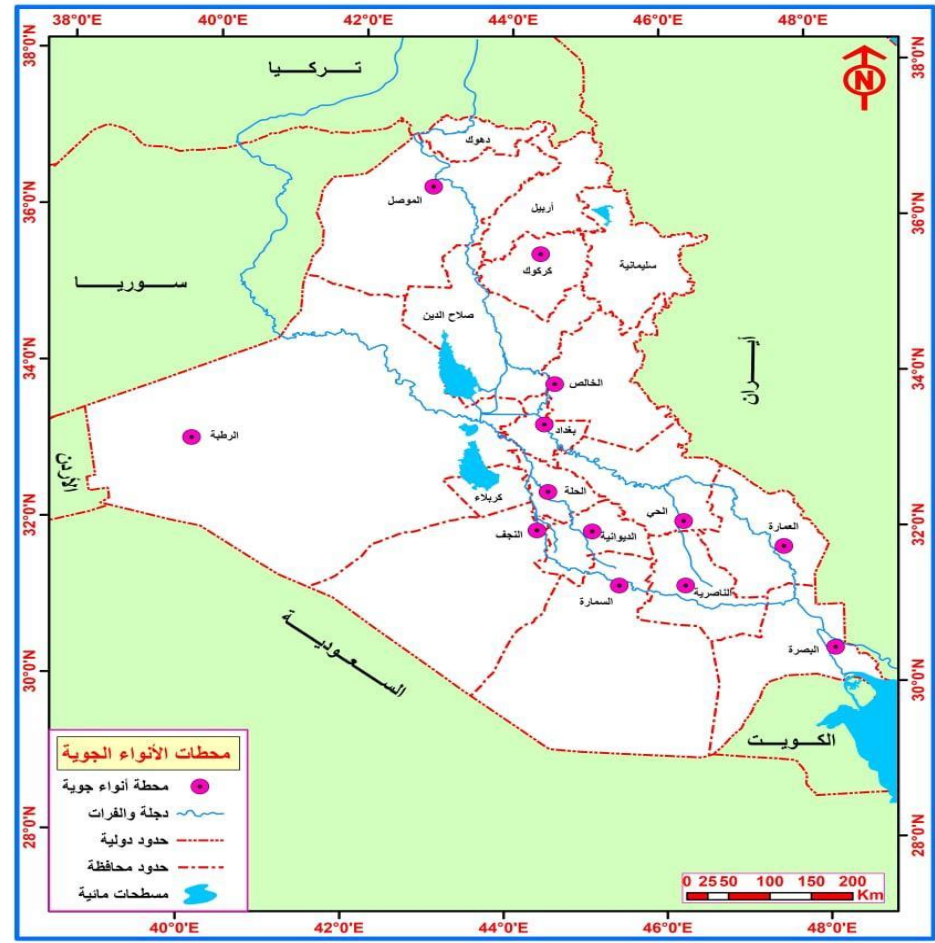

The source / the study is depending on the Ministry of Transport, the Iraqi General Authority for - Study the monthly frequency of middle-level cloud cover $(\mathrm{CM})$

Meteorology and Seismic Monitoring, Climate

Section

Characteristics and indications of types of middle-level clouds as shown in Table (1)

\begin{tabular}{|l|l|l|}
\hline Their characteristics & Symbol & Clouds type \\
\hline $\begin{array}{l}\text { In most of its parts, it is formed as a result of } \\
\text { the continuous and gradual development of } \\
\text { the Cs }\end{array}$ & As1 & $\begin{array}{l}\text { Middle-level } \\
\text { translucent }\end{array}$ \\
\hline $\begin{array}{l}\text { They are so dark clouds that they obscure the } \\
\text { sun and the moon, and they are often } \\
\text { accompanied by more low clouds that form } \\
\text { under its base or mix in it at times. }\end{array}$ & & Stratigraphy \\
\hline $\begin{array}{l}\text { It is in the form of stacked pieces on a single } \\
\text { flat surface, and it tends to spread gradually } \\
\text { and slowly in the sky }\end{array}$ & Ac3 & Middle-level clouds translucent \\
\hline $\begin{array}{l}\text { It is pieces irregular and its shapes change } \\
\text { constantly and the reason for the change is } \\
\text { that these clouds are thin and translucent and } \\
\text { are often seen over mountain areas }\end{array}$ & Ac4 & Middle-level clouds almond \\
\hline $\begin{array}{l}\text { In the form of thin and translucent bundles } \\
\text { consisting of one or a few continuous layers, } \\
\text { this type tends to spread in the sky with an } \\
\text { increase in its thickness in general }\end{array}$ & & Ac5 \\
\hline $\begin{array}{l}\text { It is formed as a result of the spread of the } \\
\text { upper parts of the Cu cumulus clouds, which } \\
\text { have a large vertical extension and be in the } \\
\text { form of large, dark and thick swellings, and } \\
\text { then they soon thin and tear }\end{array}$ & & Middle-level Beam clouds \\
\hline
\end{tabular}




\begin{tabular}{|l|l|l|}
\hline $\begin{array}{l}\text { Some parts of it are usually dark and do not } \\
\text { tend to spread in the sky, and it may be } \\
\text { opaque and be accompanied by a middle or } \\
\text { stratified cloud. }\end{array}$ & & Clouds type \\
\hline $\begin{array}{l}\text { And it is in the form of pages or layers on } \\
\text { different levels, translucent or opaque, and its } \\
\text { parts do not change constantly and do not tend } \\
\text { to spread in the sky }\end{array}$ & & $\begin{array}{l}\text { Middle-level layer thin } \\
\text { translucent }\end{array}$ \\
\hline $\begin{array}{l}\text { It is a middle, stratified, and medium-weight } \\
\text { rubble, and these clouds cannot be seen due to } \\
\text { darkness, dust or sand storms, or any other } \\
\text { phenomenon that blocks the view of the sky }\end{array}$ & & Stratigraphy \\
\hline
\end{tabular}

Source / the research relies on Maha Eisa Tawfiq alDalu "the general trend of cloud cover and its impact on precipitation in Iraq, study in climate geography, College of GirlsType 1: Altostratus (As1) intermediate layer.

Altostratus (As1) translucent type

It appears from table (2) and figure (1) that the first type is altostratus translucent medium (AS1), which is one of the types of middle-level clouds. The highest annual average monthly recurrence is recorded in time during (March April May) for the stations of the study area due to the effect of depressions of the Mediterranean (frontline), especially the warm and applied front, as well as the impact of the Sudanese depression during the spring months, specifically April. Spatially, the highest annual rate of the monthly recurrence of this type was recorded at Diwaniyah station, reaching (9.4) Nasiriyah (9.1) Samawah. (8.5) Al-Hayy (8.4) Mosul (7.8) Rutba (7.5) Kirkuk (6.2) then Najaf and Basra (4.8) ) For each of them, respectively, Hilla (4.5), Baghdad (2.8), Khalis (2.3), and finally, Emaraa (0.8). Education, University of Baghdad, 2016, p.92

\begin{tabular}{|c|c|c|c|c|c|c|c|c|c|c|c|c|c|}
\hline August & July & June & May & April & March & February & ك5 & 1 & No 2 & No1 & September & Stations & \\
\hline 0.1 & 0.2 & 0.6 & 5.5 & 7.8 & 7.4 & 5.1 & 4.7 & 4.4 & 2.7 & 1.7 & 0.2 & Mosul & AS 1 \\
\hline 0.2 & 0.1 & 0.7 & 4.8 & 6.2 & 5 & 3.3 & 3.2 & 2.7 & 2.3 & 1.5 & 0.2 & Kirkuk & AS 1 \\
\hline $\mathbf{0}$ & 0.1 & $\overline{\mathbf{0}}$ & 1.5 & 1.2 & 2.3 & 2 & 0.6 & 0.5 & 0.5 & 0.6 & 0.3 & Khalis & AS 1 \\
\hline 0.1 & $\overline{\mathbf{0}}$ & $\overline{0}$ & 1.2 & 2.4 & 2.8 & 1.9 & 1.6 & 1.9 & 1.1 & 0.6 & 0.1 & Baghdad & AS 1 \\
\hline 0 & $\overline{0}$ & $\overline{0}$ & 1.8 & 4.5 & 3 & 2.3 & 2.7 & 2.6 & 2 & 1.6 & 0.2 & Hillah & AS 1 \\
\hline 0.5 & 0.2 & 0.8 & 8.4 & 7.8 & 6.2 & 6.8 & 6.2 & 5.3 & 3.8 & 3.8 & 0.7 & Al-Hayy & AS 1 \\
\hline 0.3 & 0.2 & 1.2 & 5.7 & 7.5 & 4.7 & 3.6 & 3.4 & 3.4 & 2 & 2.3 & 1.1 & Rutbah & AS 1 \\
\hline 0.1 & $\mathbf{0}$ & 0.2 & 4.2 & 4.8 & 4.2 & 3 & 2.8 & 3.3 & 2.1 & 1.6 & 0.1 & Najaf & AS 1 \\
\hline 0.1 & $\mathbf{0}$ & 0.4 & 7.3 & 9.4 & 6.7 & 6.2 & 6.6 & 5.2 & 3.7 & 2.4 & 0.6 & Diwaniyah & AS 1 \\
\hline 0.3 & $\mathbf{0}$ & 1 & 7.7 & 8.5 & 7 & 7.1 & 4.7 & 5.2 & 2.1 & 2.4 & 0.3 & Samawah & AS 1 \\
\hline $\mathbf{0}$ & $\mathbf{0}$ & $\mathbf{0}$ & 0.8 & 0.5 & 0.6 & 0.1 & 0.5 & 0.2 & 0.4 & 0.1 & $\mathbf{0}$ & Amarraa & AS 1 \\
\hline $\mathbf{0}$ & 0.2 & 0.5 & 7.2 & 9.1 & 9 & 5 & 5.4 & 6 & 5 & 2.5 & 0.2 & Nasiriyah & AS 1 \\
\hline $\mathbf{0}$ & $\mathbf{0}$ & 0.3 & 2.4 & 4.8 & 3.2 & 2.7 & 3 & 2.5 & 2 & 1.6 & 0 & Basra & AS 1 \\
\hline
\end{tabular}



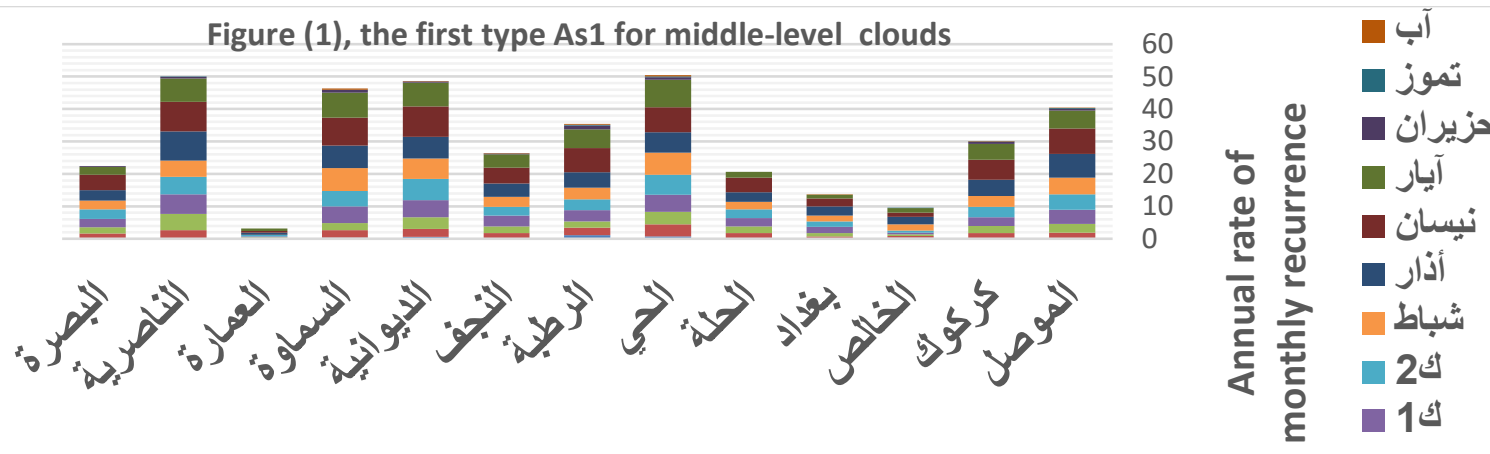

Source: the work is based on Table (2)

As for the lowest annual rate of the monthly recurrence of the type (AS1), altostratus translucent average, its value was very little, especially during the summer months on all stations of the study area This type of clouds was more frequent on the southern stations, as the air masses reaching them lose a lot of their moisture as they travel vast distances from the land coming from sources that originated from the water bodies adjacent to Iraq and therefore they lose a lot of moisture. It becomes modified air masses that contribute to the emergence of thick layer clouds and thin layer clouds appearing during the spring months, where the water content of the air masses dominate Iraq is less than winter. So, the spring months noticed the highest appearance of these clouds. The central stations, including the Rutba one, were more affected by the Mediterranean frontal depressions, the applied warm front effect, and the merging depressions more affected compared to Baghdad station.

Type 2: Nimbostratus (NS2)

From following table (3) and figure (2), we note that the second type (NS2) is a nimbostratus clouds, which recorded the highest annual rate of monthly recurrence in time during the winter months, specifically (December and January) and the spring months (March and April) at the study period. These clouds are formed from a steady air rising of approximately $20 \mathrm{~cm} / \mathrm{s}$, especially with the warm front, as affected by the study area by the frontal depressions as well as the Sudanese depressions which are merging due to the activity of the upward air movement in the warm months during the warm rainy months, the front depressions and the warm fronts. As for the spatial distribution of this type, it recorded the highest annual average monthly recurrence according to the sequence of stations starting from Mosul, which took the leadby reaching ((29.7) because the Siberian high consists of a cold air mass $(\mathrm{Cb})$, which makes it deep on the surface and shallow in the upper atmosphere. This allows the impact of this altitude with humid air depressions at the level of (850) millibars leading to the formation of this type of clouds, in addition to the influence of the European high and the Al-Hayy recorded (26.3, then Nasiriyah (22.7) Al-Rutba (19.1) And Hilla (15.7) Basra (15) Kirkuk (11.2) Najaf (9.7) Samawah (9) Baghdad (8.2) Diwaniyah (7.9) then Al Khalis (5.3) and finally Al Emara (4.2) )

As for the lowest annual rate for this type, it was recorded during the summer months, including (June, July, August) for most stations in the study area, and in place, the stations in Mosul, Baghdad, Hilla, Najaf, Diwaniyah, reached (0.1) for each station, respectively, then the stations, Samawah, Amara, Basra (0.2). ) For each station respectively, and the two stations of Al-Khalis and Al-Hayy (0.3) for each of them, Kirkuk and Al-Rutba (0.5) for each station, and finally Nasiriyah (0.7)

The stratigraphic equation is closely related to the depression, where it is the last end of a series of successive stratigraphic periosteum, the high stratified periosteum, and the middle stratigraphic cloud, then the stratified balance, and although it is generally associated on warm fronts, it is also present on cold and closed fronts. The middle-level cumulus periosteum and stratum periosteum turn into a thick layer of clouds, and it may sometimes arise from the active cumulus pyogenic systems or even the accumulated low accumulated periosteum, but in this case only a relatively small area is affected, unlike the large areas it covers in the depression. 
Table (3) Annual average of the monthly recurrence of the second type of middle-level clouds

\begin{tabular}{|c|c|c|c|c|c|c|c|c|c|c|c|c|c|}
\hline August & July & June & May & April & March & February & 25 & 1 & 2 & $1 ت$ & September & Stations & \\
\hline $\mathbf{0}$ & 0.1 & 0.6 & 6.5 & 14.2 & 17.2 & 21.2 & 29.7 & 22.3 & 11.3 & 4 & 0.2 & Mosul & NS 2 \\
\hline $\mathbf{0}$ & 0.5 & 0.6 & 7.8 & 11.2 & 10.5 & 10.3 & 10.2 & 10.5 & 6.4 & 4.7 & 0.7 & Kirkuk & NS 2 \\
\hline 0.3 & 0 & 0.4 & 3.4 & 3.5 & 5.3 & 3.8 & 4.2 & 3.1 & 1.8 & 1.6 & 0.3 & Khalis & NS 2 \\
\hline $\mathbf{0}$ & $\mathbf{0}$ & 0.1 & 2.3 & 5.5 & 4.9 & 5.5 & 8.2 & 6.5 & 4.1 & 1.5 & 0.2 & Baghdad & NS 2 \\
\hline 0 & $\mathbf{0}$ & 0.1 & 2.3 & 6.2 & 7.7 & 11.1 & 15.7 & 11.3 & 7.9 & 2.2 & 0.1 & Hillah & NS 2 \\
\hline 0.5 & 0.3 & 0.8 & 14.9 & 19.5 & 19.6 & 20.5 & 25.7 & 26.3 & 16.8 & 10.1 & 0.8 & Al-Hayy & NS 2 \\
\hline 0 & $\mathbf{0}$ & 0.5 & 11.8 & 13.8 & 14.9 & 17.3 & 19.1 & 15.5 & 7.6 & 7 & 0.9 & Rutba & NS 2 \\
\hline 0.1 & 0 & $\mathbf{0}$ & 3.2 & 5.3 & 6.3 & 7 & 9.7 & 9.1 & 5 & 1.8 & 0.2 & Najaf & NS 2 \\
\hline $\mathbf{0}$ & 0.1 & 0.1 & 3.7 & 5.3 & 4.8 & 5.4 & 7.9 & 5.7 & 5.7 & 2.7 & $\mathbf{0}$ & Diwaniyah & NS 2 \\
\hline 0.3 & $\mathbf{0}$ & 0.2 & 6.9 & 9 & 6.4 & 5.2 & 7 & 5.8 & 3.6 & 2.7 & 0.3 & Samawah & NS 2 \\
\hline $\mathbf{0}$ & $\mathbf{0}$ & $\mathbf{0}$ & 0.7 & 1.3 & 1.3 & 2.1 & 4.2 & 1.9 & 1.6 & 0.2 & $\mathbf{0}$ & Amarra & NS 2 \\
\hline $\mathbf{0}$ & $\mathbf{0}$ & 0.7 & 10.3 & 18.2 & 15.7 & 17.3 & 22.7 & 21.7 & 12.3 & 7.1 & 0.7 & Nasiriyah & NS 2 \\
\hline 0.2 & $\mathbf{0}$ & 0.2 & 5 & 9.6 & 9.9 & 11.3 & 15 & 14.8 & 7.8 & 1.6 & $\mathbf{0}$ & Basra & NS 2 \\
\hline
\end{tabular}
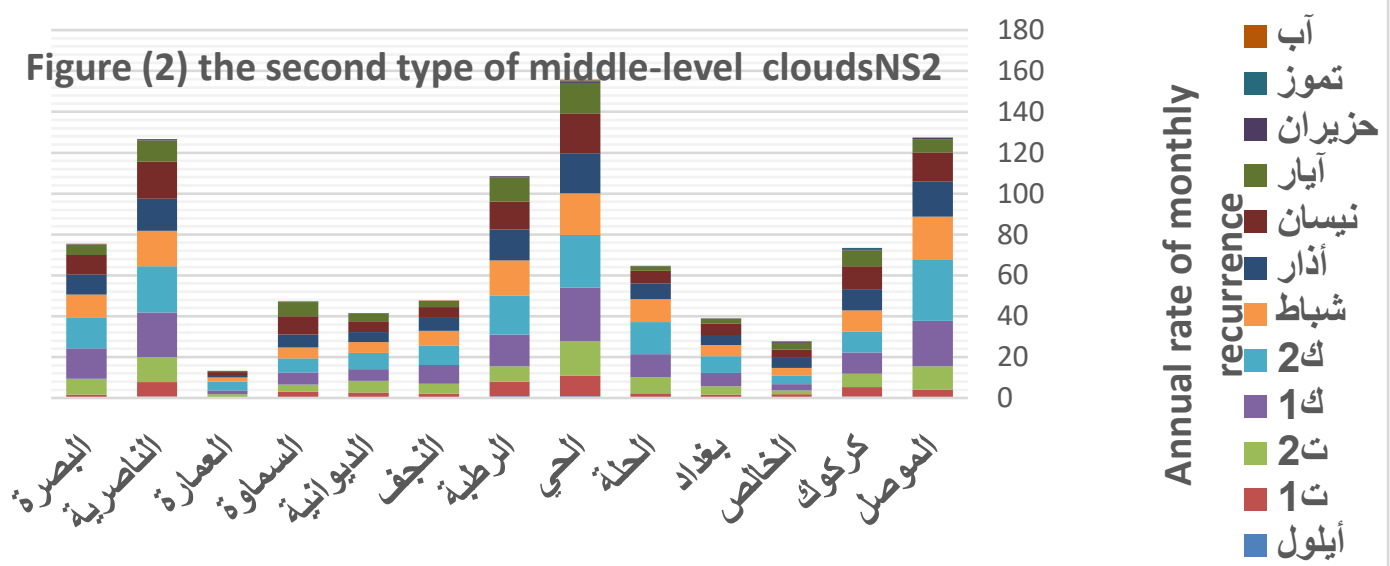

Type 3: Altostratus semitransparent clouds (AS3)

It appears from Table (4) and Figure (3) that the third type (AS3) is amiddle-level semitransparent clouds that recorded the highest annual rate of monthly recurrence in time during December due to the impact of frontal depressions, especially the cold and full front and Sudanese depressions and the autumn months (October and November). As for the spatial distribution of the highest annual rate of monthly recurrence of this species, it was led by the central 
region, specifically Baghdad, with the first place being (50.1) due to the impact of the Mediterranean, Sudanese, semi-tropical frontal depressions, and Basra 42.3) due to its proximity to the source of moisture represented by the Arabian Gulf, Kirkuk (36.1) as a result of the influence of the European and Siberian high, which is the closest station to its influence on Mosul (34.1) Amara (32.3) Al-Rutbah (32.2) An Nasiriyah (30.3) Al-Samawah (27.7) AlKhalis (23.2) Al-Diwaniyah (21.0) Najaf (18.8) (17.9) and finally Hillah (16.9)

As for the lowest annual average monthly recurrence of the third type (AS3), it was recorded during the summer, specifically June, for all stations in the study area, the district station recorded (1.7) Al-Khalis (3.2) Al-Hillah (3.3 (Najaf) 3.4 (Al-Diwaniyah) 3.5) Al-Samawah 3.9 (Amara) 5 (Basra) 5.4 (then AlRutba and Nasiriyah stations) 6.1) for each station respectively, and the Kirkuk and Baghdad stations (7.8) for each of them, and finally the Mosul station (11.2)

Type 4: Altocumulus clouds (AC4)
This type is balls-like units with white or single color or groups and the group includes a smaller or spherical group that resembles ribbons.

It appears from Table (5) and Figure (4) that the temporal distribution of the highest annual rate of monthly recurrence of the fourth type (AC4) middlelevel altocumulusclouds recorded during the autumn months (October and November) and the winter months (December and January) and then the spring months (March \& April). This type of clouds is affected by the recurrence of cold and full fronts, middle-level frontal lows and Sudanese and merging lows, in addition to the influence of the Siberian and European high air heights. (Al-Khalis) 6.3 (Al-Rutba) 3.3 (Najaf) 2.4 (Mosul) 1.9 (Samawah) 1.5 (Kirkuk) 1.4 Then the two stations of Baghdad and Al Hayy (1) for each station respectively, and Hilla (0.6), Al Amarah (0.5) and Nasiriyah (0.4) and finally Basra (0.2)

With regard to the lowest annual average monthly frequency of the fourth type (AC4), it was recorded during the summer months for most stations in general

\begin{tabular}{|c|c|c|c|c|c|c|c|c|c|c|c|c|c|}
\hline August & July & June & May & April & March & February & 25 & 1 ك & 2 & ت & September & Stations & \\
\hline 12.5 & 11.2 & 13.1 & 27.8 & 22.7 & 23.4 & 25.2 & 24.8 & 30.6 & 29.4 & 34.1 & 12.1 & Mosul & AS 3 \\
\hline 10.7 & 9.1 & 7.8 & 26.7 & 27.9 & 29.2 & 29.4 & 30.7 & 33.5 & 33.2 & 36.1 & 10.6 & Kirkuk & AS 3 \\
\hline 4 & 3.6 & 3.2 & 17.8 & 16.6 & 16.3 & 16.4 & 18.6 & 23.2 & 18.5 & 18.3 & 7.1 & Khalis & AS 3 \\
\hline 12.7 & 11.8 & 7.8 & 38.2 & 40.8 & 40.9 & 40.8 & 42.3 & 50.1 & 45.6 & 46.4 & 14.5 & Baghdad & AS 3 \\
\hline 8.3 & 8.1 & 3.3 & 12.4 & 12.1 & 13 & 12.2 & 15.5 & 16.5 & 16.9 & 23 & 9.3 & Hillah & $\overline{A S ~} 3$ \\
\hline 5.7 & 5.5 & 1.7 & 12.6 & 15.4 & 14.2 & 14.3 & 14.2 & 13.9 & 17.9 & 16.6 & 4.8 & Al-Hayy & AS 3 \\
\hline 7.9 & 6.3 & 6.1 & 19.9 & 16.8 & 20.4 & 20.6 & 22.5 & 29.7 & 26.1 & 32.2 & 12.8 & Rutba & AS 3 \\
\hline 5.4 & 3.8 & 3.4 & 14 & 11.9 & 14.7 & 13 & 13.8 & 17.5 & 14.9 & 18.8 & 7.5 & Najaf & AS 3 \\
\hline 10.7 & 6.3 & 3.5 & 14.6 & 14.4 & 14.8 & 15 & 16 & 21 & 20.1 & 20.2 & 7.9 & Diwaniyah & AS 3 \\
\hline 9 & 10.3 & 3.9 & 17.1 & 16.8 & 14.2 & 16.4 & 18.8 & 23.3 & 26.5 & 27.7 & 9.6 & Samawah & AS 3 \\
\hline 8.3 & 9.7 & 5 & 21.5 & 25.3 & 28.5 & 24.8 & 25.8 & 30.9 & 32.3 & 23.1 & 8 & Amara & AS 3 \\
\hline 10.4 & 8 & 6.1 & 20.1 & 21.6 & 22.4 & 23 & 25.8 & 27.1 & 30.3 & 28.9 & 11.4 & Nasiriyah & AS 3 \\
\hline 14.6 & 17.4 & 5.4 & 27.6 & 28.2 & 26.2 & 29.3 & 34.4 & 42.3 & 41.2 & 29.4 & 12.3 & Basra & AS 3 \\
\hline
\end{tabular}

Source: The researcher's work relying on the Iraqi General Authority for Meteorology, Climate Section, unpublished (hourly) cloud data 1988-2018 

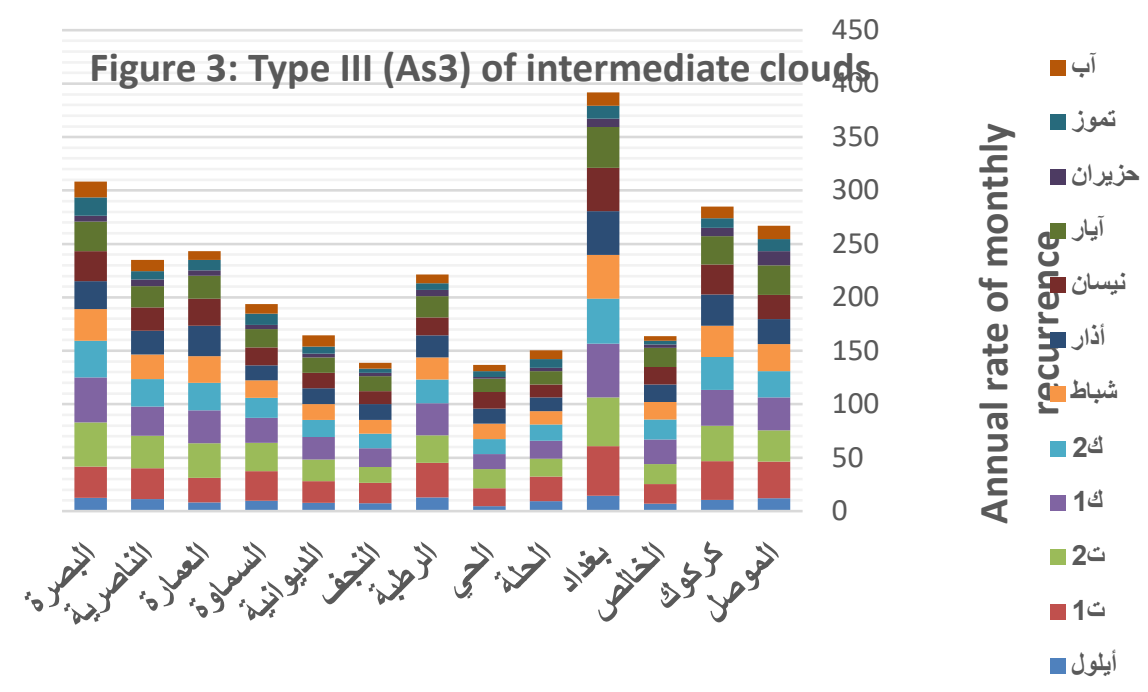

The source of the researcher's work based on Table (4)

\begin{tabular}{|c|c|c|c|c|c|c|c|c|c|c|c|c|c|}
\hline August & July & June & May & April & March & February & كפ2 & 15 & 2ت & ت1 & September & Stations & \\
\hline 0.1 & 0.2 & 0.6 & 1.1 & 1.3 & 1.8 & 1.1 & 1.5 & 1 & 1.9 & 1.9 & 0.3 & Mosul & $\overline{A C ~} 4$ \\
\hline $\mathbf{0}$ & 0.1 & 0.1 & 1 & 1.4 & 1.3 & 0.7 & 0.7 & 0.3 & 0.6 & 0.3 & $\overline{\mathbf{0}}$ & Kirkuk & $\overline{A C ~} 4$ \\
\hline 1.3 & 1 & 1.2 & 4 & 4.7 & 3.5 & 4.6 & 6 & 5.8 & 4.9 & 6.3 & 1.7 & khalis & $\overline{A C ~} 4$ \\
\hline 0 & $\mathbf{0}$ & 0.2 & 0.4 & 0.7 & 0.8 & 0.9 & 0.8 & 0.6 & 1 & 0.5 & 0.1 & Baghdad & $\overline{A C ~} 4$ \\
\hline 0.1 & 0.1 & $\mathbf{0}$ & 0.2 & 0.1 & 0.5 & 0.6 & 0.5 & 0.4 & 0.3 & 0.3 & 0.2 & Hillah & $\overline{A C ~} 4$ \\
\hline 0.1 & $\mathbf{0}$ & $\overline{\mathbf{0}}$ & 0.7 & 0.6 & $\overline{1}$ & 1 & 0.8 & 1 & 0.7 & 0.3 & $\overline{\mathbf{0}}$ & Neighborhood & $\overline{A C 4}$ \\
\hline 0.3 & 0.2 & 0.3 & 1.1 & 1.2 & 2.5 & 2 & 2.7 & 2.1 & 3 & 3.3 & 0.1 & Rutba & $\overline{\mathrm{AC} 4}$ \\
\hline 0.3 & 0.3 & 0.1 & 0.9 & 1.8 & 2.3 & 1.5 & 1.9 & 2 & 2.4 & 2.1 & 0.6 & Najaf & $\overline{A C 4}$ \\
\hline 1.2 & 0.8 & 0.9 & 3 & 3.7 & 5.8 & 5.7 & 5.1 & 6.9 & 7.1 & 4.4 & 1.3 & Diwaniyah & $\overline{A C ~} 4$ \\
\hline 0.2 & 0.2 & $\mathbf{0}$ & 0.8 & 0.9 & 0.8 & 1.2 & 1.5 & 1.5 & 1.2 & 1 & 0.2 & Samawah & AC 4 \\
\hline 0.1 & $\mathbf{0}$ & $\overline{0}$ & 0.3 & 0.5 & 0.4 & 0.5 & 0.4 & 0.2 & 0.5 & 0.3 & $\overline{0}$ & Amara & $\overline{A C ~} 4$ \\
\hline $\mathbf{0}$ & $\mathbf{0}$ & 0.1 & 0.3 & 0.1 & 0.2 & 0.4 & 0.2 & 0.3 & 0.2 & $\mathbf{0}$ & $\mathbf{0}$ & Nasiriyah & $\overline{A C ~} 4$ \\
\hline 0 & 0 & 0 & 0 & 0.1 & 0.2 & 0 & 0.1 & 0.2 & 0.2 & 0 & 0 & Basra & AC 4 \\
\hline
\end{tabular}

Source: The researcher's work relying on the Iraqi General Authority for Meteorology, Climate Section, unpublished (hourly) cloud data2018-1988 


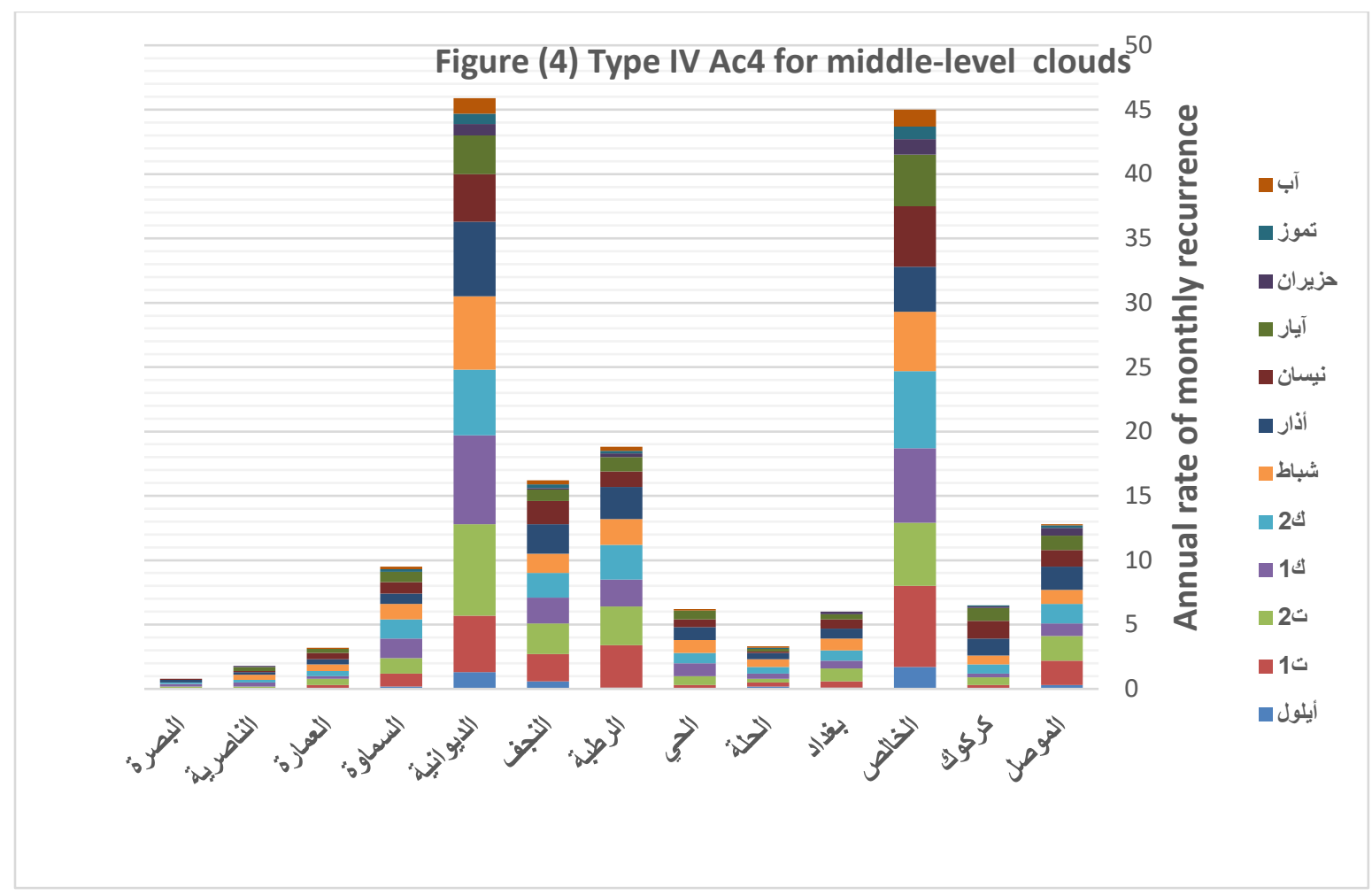

Source: the research work is based on Table (5)

\section{Type 5: Altocumulus clouds (AC5)}

It is evident from Table (6) and Fig (5) that an annual average of the monthly recurrence of the fifth type is the middle-level altocumulus clouds (AC5). The temporal distribution was recorded during the winter months (December and January) except for the two stations of Al-Hilla and Al-Amara during November, it is affected by atmospheric highlands, including Siberian, European, subtropical, merging heights, intermediate frontal lows, Sudanese low and merging spatially. The highest annual average monthly recurrence (AC5) from middle-level cloud was according to the sequence of stations starting from Al-Hayy, it reached (8). This is due to the effect of the cold and full fronts accompanying the middle frontal fronts and the impact of the Sudanese depression for their location in the southwestern part of Baghdad (7.8) Najaf and Samawah (7.7) for each of them, respectively, (6.1)) (Al-Khalis) 4.9 (Diwaniyah) 4.4 (then Hilla) 3.2 Al-Rutba (2.5) Kirkuk 2.3 (Basra) 1.5 Nasiriyah (1.2) and finally Amara (0.8)

As for the lowest annual average of the monthly recurrence of this type, it was recorded during the summer months (June, July and August) in addition to the month of September for Al-Amara station, starting from the stations, Kirkuk Al-Khalis Al-Rutba Al-Hilla Al-Rutba Al-Diwaniyah Al-Amara AlBasrah, you reached (0.1) for each station, respectively, then Mosul, Baghdad. Samawah Nasiriyah (0.2 per station, respectively, Najaf (0.3), then Al-Hayy(0.4).

Type 6: (AC6 arising from flatulence of cumuliform clouds) Altocumulus (AC6)

It is observed from the Table (7) and Fig. (6) that the highest annual rate of monthly recurrence of the sixth type (AC6) middle-level altocumulus clouds arising from cumuliform, one of the types of middle-level clouds distributed in time during the autumn months (October and November) and the winter months January and then the spring months (March and April) due to the effect of the Mediterranean frontal depressions and the effect of the cold and full front and the combined depressions as the turbulent movement of the rising air is high that encourages the formation of this type of clouds in addition to the effect of the air heights spatially. Baghdad station recorded first place In the frequency of this type of clouds compared to other stations during the study period, it reached (7.4), then Najaf (2.1), Diwaniyah (1.6), Mosul (1.5). 
Table (6) Annual average of the monthly recurrence, type V, AC5, for middle-level clouds

\begin{tabular}{|c|c|c|c|c|c|c|c|c|c|c|c|c|c|}
\hline August & July & June & May & April & March & February & $2^{\text {⿹ }}$ & $1^{5}$ & ت & ت1 & September & Stations & \\
\hline 0.2 & 0.3 & 0.2 & 1.7 & 2.2 & 2.8 & 4.1 & 5 & 6.1 & 4.6 & 2.2 & 0.5 & Mosul & AC 5 \\
\hline 0.2 & 0.1 & $\mathbf{0}$ & 0.7 & 0.5 & 0.7 & 0.8 & 1.1 & 2.3 & 1.5 & 0.7 & $\mathbf{0}$ & Kirkuk & AC 5 \\
\hline 0.3 & 0.1 & 0.1 & 1.5 & 2.2 & 2.9 & 2.3 & 3.7 & 4.9 & 3.9 & 2.8 & 0.2 & khalis & AC 5 \\
\hline 0.4 & 0.4 & 0.2 & 1.5 & 1.5 & 2.7 & 3.9 & 6.3 & 7.8 & 4.2 & 2.4 & 0.3 & Baghdad & AC 5 \\
\hline 0.2 & 0.1 & 0.2 & 1.3 & 1.3 & 1.5 & 2 & 2.4 & 2.6 & 3.2 & 2 & 0.1 & Hillah & AC 5 \\
\hline 0.7 & 0.6 & 0.4 & 2.6 & 4.2 & 4.3 & 6.5 & 8 & 7.8 & 7 & 3.7 & 0.4 & Neighborhood & AC 5 \\
\hline $\mathbf{0}$ & 0.1 & 0.2 & 0.5 & 0.5 & 1.3 & 1.5 & 2.5 & 1.5 & 1.4 & 0.9 & $\mathbf{0}$ & Rutba & AC 5 \\
\hline 0.7 & 0.3 & 0.4 & 1.9 & 3.4 & 3 & 4 & 5.7 & 7.7 & 7.5 & 3.5 & 0.3 & Najaf & AC 5 \\
\hline 0.5 & 0.6 & 0.1 & 1.9 & 2.8 & 2.5 & 3.1 & 3.7 & 4.4 & 3.3 & 2.3 & 0.7 & Diwaniyah & AC 5 \\
\hline 1.2 & 0.2 & 0.5 & 4.3 & 5 & 5 & 7.7 & 5 & 6.4 & 7 & 5.3 & 0.5 & Samawah & AC 5 \\
\hline 0.1 & $\mathbf{0}$ & $\mathbf{0}$ & 0.2 & 0.2 & 0.3 & 0.2 & 0.7 & 0.3 & 0.8 & 0.4 & 0.1 & Amara & AC 5 \\
\hline 0.2 & $\mathbf{0}$ & $\mathbf{0}$ & 0.5 & 0.5 & 0.3 & 1.1 & 0.9 & 1.2 & 0.3 & 0.3 & $\mathbf{0}$ & Nasiriyah & AC 5 \\
\hline 0.1 & 0.3 & 0.2 & 0.5 & 0.5 & 1.3 & 1 & 1.2 & 1.5 & 0.9 & 0.2 & $\mathbf{0}$ & Basra & AC 5 \\
\hline
\end{tabular}

Source: The researcher's work relying on the Iraqi General Authority for Meteorology, Climate Section, unpublished (hourly) cloud data2018-1988
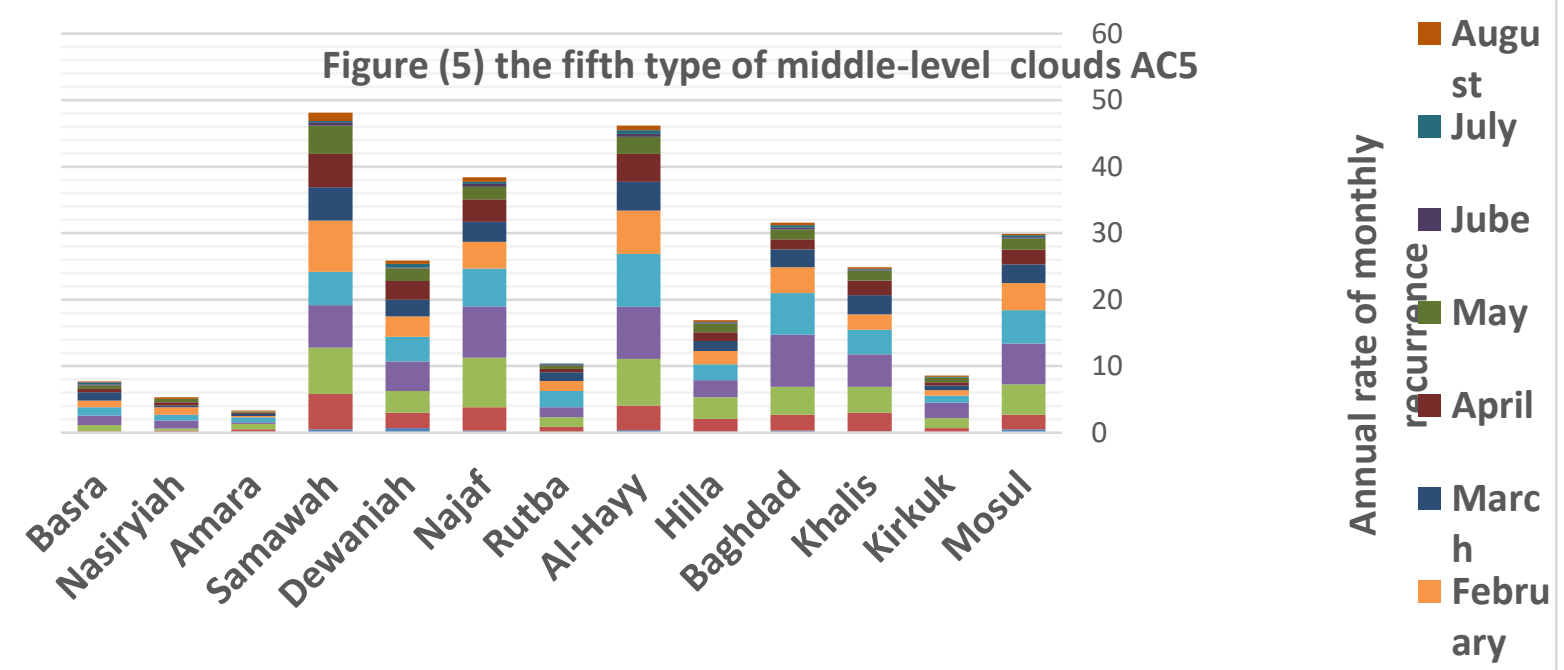

Table (7) Annual average of the monthly recurrence, type VI, AC6, for middle-level clouds

\begin{tabular}{|c|c|c|c|c|c|c|c|c|c|c|c|c|c|}
\hline August & July & June & May & April & March & February & ك5 & ك & 2 & 1 & September & Stations & \\
\hline 0.2 & 0.3 & 0.9 & 1.4 & 1.2 & 0.8 & 0.5 & 0.7 & 0.3 & 0.9 & 1.5 & 0.3 & Mosul & AC 6 \\
\hline 0 & $\mathbf{0}$ & 0.1 & 0.3 & 0.7 & 0.8 & 0.7 & 0.4 & 0.7 & 0.4 & 1.1 & $\mathbf{0}$ & Kirkuk & AC 6 \\
\hline
\end{tabular}




\begin{tabular}{|c|c|c|c|c|c|c|c|c|c|c|c|c|c|}
\hline $\mathbf{0}$ & 0 & 0 & 0.5 & 1.1 & 0.8 & 0.3 & 0.5 & 0.1 & 0.3 & 0.5 & 0.1 & khalis & $\overline{A C ~} 6$ \\
\hline 0.7 & 0.3 & 0.7 & 4.2 & 3.7 & 5.9 & 5 & 4.8 & 5 & 6.5 & 7.4 & 1 & Baghdad & $\overline{A C ~} 6$ \\
\hline 0.1 & 0 & $\mathbf{0}$ & 0.2 & 0.2 & 0.3 & 0.2 & 0.3 & 0.1 & 0.2 & 0.2 & 0.1 & Hillah & AC 6 \\
\hline $\mathbf{0}$ & $\mathbf{0}$ & $\mathbf{0}$ & 0.2 & 0.3 & $\mathbf{0}$ & 0.6 & $\mathbf{0}$ & 0.5 & 0.3 & $\mathbf{1}$ & $\mathbf{0}$ & Neighborhood & AC 6 \\
\hline $\mathbf{0}$ & $\overline{\mathbf{0}}$ & $\overline{\mathbf{0}}$ & 0.1 & 0.2 & 0.1 & $\overline{\mathbf{0}}$ & 0.1 & 0.1 & $\overline{\mathbf{0}}$ & $\mathbf{0}$ & $\mathbf{0}$ & Rutba & AC 6 \\
\hline $\mathbf{0}$ & $\mathbf{0}$ & 0.3 & 0.6 & 1.1 & 1.3 & 1.8 & 2.1 & 1.8 & 2 & 1.1 & 0.1 & Najaf & $\overline{A C 6}$ \\
\hline 0.2 & $\mathbf{0}$ & 0.1 & 1.2 & 1.1 & 1.3 & 1 & 0.9 & 1.3 & 1.6 & 0.8 & 0.2 & Diwaniyah & AC 6 \\
\hline $\mathbf{0}$ & $\mathbf{0}$ & $\mathbf{0}$ & 0.8 & 0.7 & 1 & 0.6 & 1 & 0.4 & 0.6 & 0.4 & 0.3 & Samawah & AC 6 \\
\hline $\mathbf{0}$ & $\mathbf{0}$ & $\overline{\mathbf{0}}$ & 0.1 & 0.4 & 0.2 & 0.2 & 0.1 & 0.1 & 0.1 & 0.1 & $\mathbf{0}$ & Amara & $\overline{A C 6}$ \\
\hline $\mathbf{0}$ & $\mathbf{0}$ & 0.1 & 0.1 & 0.1 & 0.4 & 0.2 & 0.1 & 0.4 & $\mathbf{0}$ & 0.4 & $\mathbf{0}$ & Nasiriyah & AC 6 \\
\hline 0.1 & 0 & O & 0.2 & 0.2 & 0.2 & 0.1 & 0.3 & 0.3 & 0.8 & 0.3 & $\mathbf{0}$ & Basra & AC 6 \\
\hline
\end{tabular}

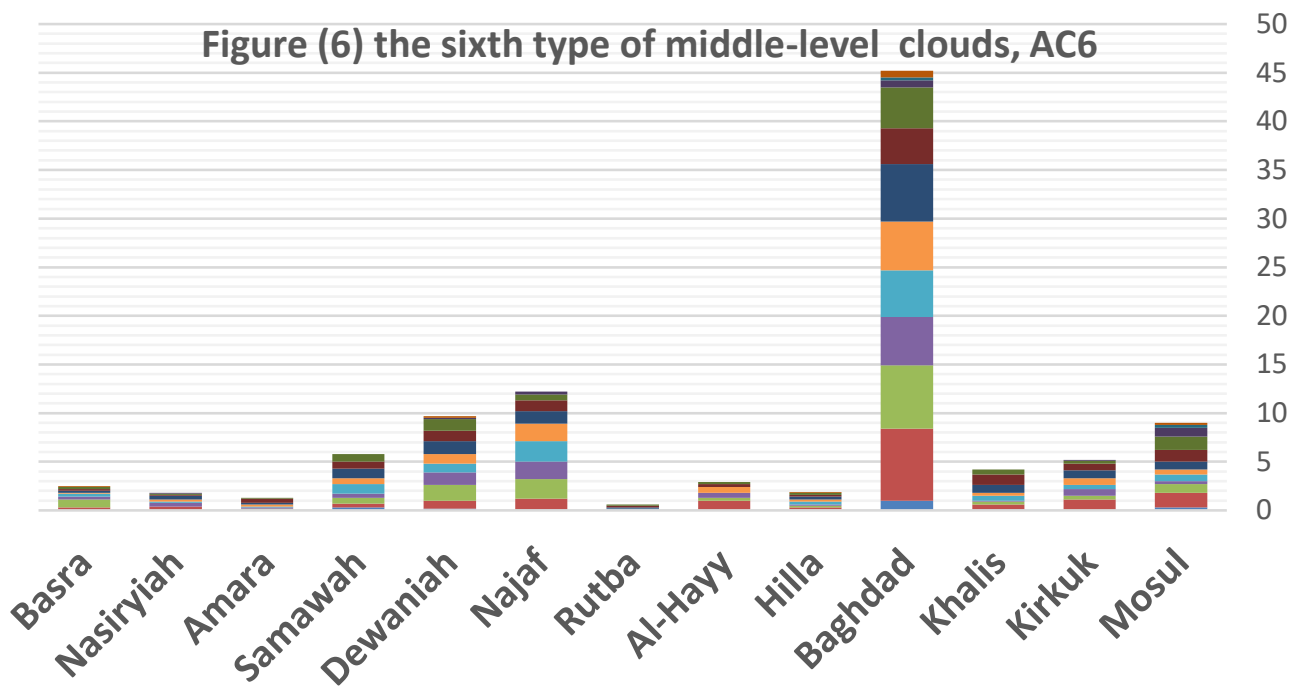

40

35

30

25

20

15

10

0
August

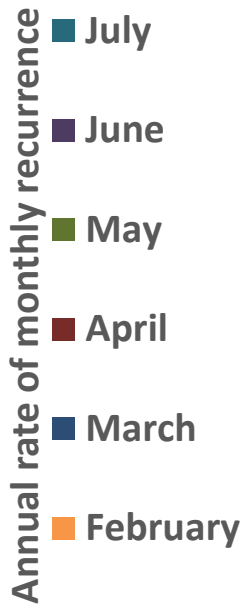

Kirkuk and Khalis recorded (1.1) for each station, respectively, and asSamawah (1) for each station, respectively, Basra (0.8) for Amara and Nasiriya (0.4), respectively. Hilla 0.3 ) and finally wet (0.2) As for the lowest annual average monthly recurrence, this type of middle-level clouds is distinguished by the fact that its frequency was few for most stations in the study area during the summer months, especially the southern stations, as well as the AlRutba station.
Type 7: Altocumulus two-layer clouds (AC7)

It appears from the following up the Table (8) and Figure (7) that on an annual average of the monthly recurrence of the seventh type (AC7) middlelevelclouds consisting of two layers in terms of temporal distribution was during the months March \& April and the winter months January and December and then months of Autumn (November). The effect of the Mediterranean frontal depressions 
and air heights include the Siberian high. As for the spatial distribution, the highest annual rate of the monthly recurrence of the seventh type (AC7) was recorded according to the sequence of stations as follows. The Khalis station was ranked first ((11.5 Baghdad (10.5) and Najaf (9.7) Nasiriya (8.8) Amara (5) Al-Hayy (4.5) Basra (4.2 Kirkuk) (3.9) Mosul (3.7) Diwaniyah (2.6) Rutba (2.4) Samawah (1.6) and finally Hillah (0.4)

With regard to the lowest annual average monthly recurrence of this type, it was recorded during (June July August) and Al-Amara station during October. It is noticeable that this type of middle-level clouds had a very low frequency on Hilla station compared to the rest of the stations during the study period in order to cover the sky with other types of clouds of different altitude levels, which are more frequent on the station of this type.

Type 8: Altocumulus cloud (AC8)

It can be seen from Table (9) and Figure (8) that the highest annual average monthly recurrence of type 8 (AC8) altocumulus cloud temporally, was recorded during October and November and December and February in order to suit the climatic conditions of condensation and the effect of heights, including the subtropical high as well as the Mediterranean frontal depressions and the cold and full fronts

As for spatially, it reached Nassiriya (2.6) and Rutba (2.0) Baghdad (1.7) Diwaniyah and Basra (1.5) for each station, respectively, Samawah (1.2). Mosul (0.8), neighborhood (0.6), Amara and Khalis (0.5), then Kirkuk (0.4), Hillah and Najaf (0.3) for each station, respectively. The high frequency rate in some central and southern stations increased the frequency of the Sudanese depression, which leads to the formation of this type of clouds compared to the northern stations.

As for the lowest annual average monthly recurrence of Type VIII (AC8), it was during the spring months (March and April) for some stations and June, July and September for most stations. As for the location of Kirkuk, Khalis, Al-Hayy, Rutba, Najaf, Nasiriyah and Amara, it reached (0.1). (Per station, respectively, then Mosul, Baghdad, Diwaniyah, Samawah and Basra) (0.2 per station respectively, and this type had very few frequencies for Hilla station during the study period.

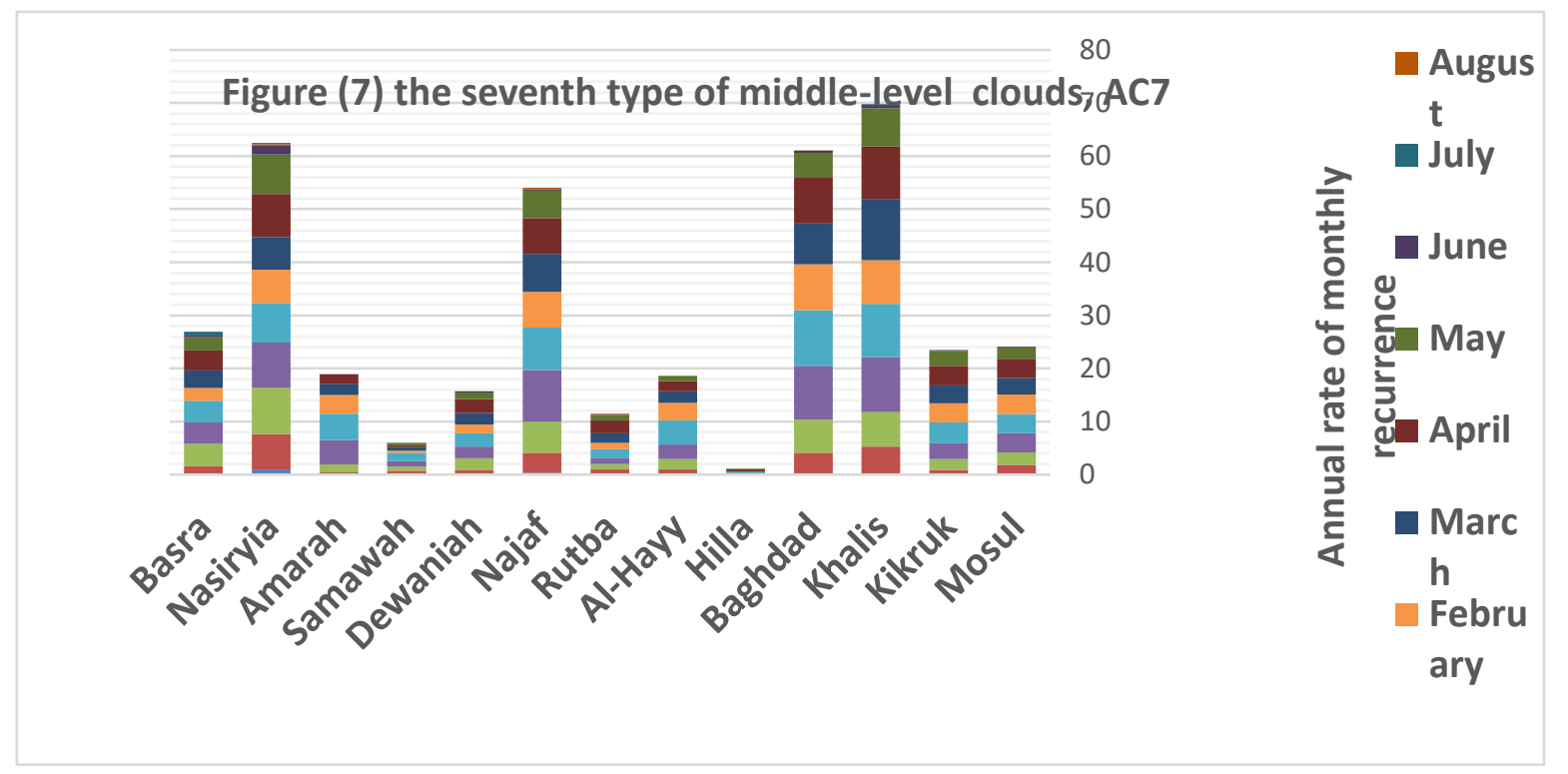

Source: the researcher's work based on Table (8)

\begin{tabular}{|c|c|c|c|c|c|c|c|c|c|c|c|c|c|}
\hline August & July & June & May & April & March & February & 25 & 15 & 2 & ت1 & September & Stations & \\
\hline $\mathbf{0}$ & 0 & 0.2 & 2.1 & 3.6 & 3.1 & 3.7 & 3.6 & 3.6 & 2.4 & 1.6 & 0.2 & Mosul & AC 7 \\
\hline 0 & $\overline{\mathbf{0}}$ & 0.2 & 2.8 & 3.7 & 3.4 & 3.6 & 3.9 & 3 & 2 & 0.7 & 0.2 & Kirkuk & AC 7 \\
\hline 0 & 0.2 & 0.6 & 7.2 & 9.9 & 11.5 & 8.2 & 10.1 & 10.3 & 6.5 & 5.1 & 0.2 & Khalis & AC 7 \\
\hline
\end{tabular}




\begin{tabular}{|l|l|l|l|l|l|l|l|l|l|l|l|l|l|}
\hline 0.1 & 0 & 0.4 & 4.7 & 8.6 & 7.7 & 8.6 & 10.5 & 10.1 & 6.3 & 3.9 & 0.2 & Baghdad & AC 7 \\
\hline 0 & 0 & 0 & 0.1 & 0.4 & 0.1 & 0.1 & 0.2 & 0.1 & 0.1 & 0 & 0 & Hillah & AC 7 \\
\hline 0 & 0 & 0 & 1 & 1.9 & 2.2 & 3.3 & 4.5 & 2.8 & 1.9 & 0.8 & 0.2 & Al-Hayy & AC 7 \\
\hline 0.2 & 0 & 0.1 & 1 & 2.4 & 1.8 & 1.2 & 1.7 & 1.1 & 1 & 0.8 & 0.2 & Rutba & AC 7 \\
\hline 0.2 & 0.1 & 0.2 & 5.2 & 6.7 & 7.2 & 6.7 & 8 & 9.7 & 5.9 & 3.8 & 0.3 & Najaf & AC 7 \\
\hline 0 & 0 & 0.2 & 1.3 & 2.6 & 2.2 & 1.6 & 2.5 & 2.2 & 2.3 & 0.7 & 0.1 & Diwaniyah & AC 7 \\
\hline 0 & 0 & 0 & 0.5 & 0.3 & 0.7 & 0.4 & 1.6 & 1 & 0.8 & 0.7 & 0 & Samawah & AC 7 \\
\hline 0 & 0 & 0 & 0 & 1.8 & 2.1 & 3.5 & 5 & 4.6 & 1.5 & 0.4 & 0 & Amara & AC 7 \\
\hline 0.3 & 0.2 & 1.7 & 7.4 & 8.2 & 6.1 & 6.3 & 7.4 & 8.5 & 8.8 & 6.6 & 1 & Nasiriyah & AC 7 \\
\hline 0 & 0.7 & 0.3 & 2.5 & 3.8 & 3.3 & 2.4 & 4.1 & 4 & 4.2 & 1.5 & 0.1 & Basra & AC 7 \\
\hline
\end{tabular}

Source: The researcher's work relying on the Iraqi General Authority for Meteorology, Climate Section, unpublished (hourly) cloud data 1988-2018

\begin{tabular}{|c|c|c|c|c|c|c|c|c|c|c|c|c|c|}
\hline August & July & June & May & April & March & February & 25 & 15 & 2 & ت & September & Stations & \\
\hline $\mathbf{0}$ & 0.4 & 0.2 & 0.8 & 0.7 & 0.6 & 0.6 & 0.4 & 0.5 & 0.8 & 0.8 & 0.2 & Mosul & AC 8 \\
\hline $\mathbf{0}$ & 0.3 & $\mathbf{0}$ & 0.1 & 0.1 & 0.2 & 0.3 & 0.4 & 0.3 & 0.3 & 0.4 & $\mathbf{0}$ & Kirkuk & AC 8 \\
\hline 0.1 & 0.3 & 0 & 0.2 & 0.3 & 0.1 & 0.4 & 0.3 & 0.1 & 0.5 & 0.1 & $\overline{0}$ & Khalis & AC 8 \\
\hline 0.2 & 0.2 & 0.3 & 0.9 & 1 & 1.1 & 1.2 & 1.5 & 1.3 & 1.7 & 1.5 & 0.2 & Baghdad & AC 8 \\
\hline 0.1 & $\overline{\mathbf{0}}$ & 0.2 & 0.2 & $\mathbf{0}$ & 0.3 & $\overline{\mathbf{0}}$ & $\mathbf{0}$ & 0.3 & 0.1 & 0.3 & 0 & Hillah & AC 8 \\
\hline 0.2 & $\mathbf{0}$ & $\mathbf{0}$ & 0.1 & 0.3 & 0.3 & 0.3 & 0.3 & 0.6 & 1 & 0.3 & 0.1 & Al-Hayy & AC 8 \\
\hline 0.3 & 0.1 & 0.3 & 1 & 0.7 & 0.7 & 0.6 & 0.8 & 1 & 1.2 & 2 & 0.3 & Rutba & AC 8 \\
\hline 0.1 & $\overline{0}$ & $\mathbf{0}$ & 0.2 & $\overline{0}$ & 0.2 & 0.3 & $\mathbf{0}$ & 0.2 & 0.1 & $\mathbf{0}$ & $\overline{0}$ & Najaf & AC 8 \\
\hline 0.2 & 0.2 & 0.2 & 1 & 1.1 & 1.3 & 0.2 & 0.9 & 0.8 & 1.5 & 1.1 & 0.2 & Diwaniyah & AC 8 \\
\hline $\mathbf{0}$ & $\overline{\mathbf{0}}$ & $\mathbf{0}$ & 0.2 & 0.2 & 0.3 & 0.7 & 0.4 & 0.5 & 1.2 & 0.7 & $\overline{0}$ & Samawah & AC 8 \\
\hline $\mathbf{0}$ & $\overline{0}$ & $\mathbf{0}$ & 0.2 & 0.2 & $\overline{0}$ & 0.2 & 0.2 & 0.2 & 0.5 & $\mathbf{0}$ & 0.1 & Amara & AC 8 \\
\hline 0.3 & 0.1 & 0.4 & 1.2 & 1.4 & 1.2 & 1.2 & 1.5 & 1.3 & 2.6 & 1.3 & 0.3 & Nasiriyah & AC 8 \\
\hline 0.6 & 0.2 & 0.4 & 0.9 & 0.9 & 1 & 1.5 & 1 & 1.3 & 1.4 & 0.9 & 0.6 & Basra & AC 8 \\
\hline
\end{tabular}

Source: The researcher's work relying on the Iraqi General Authority for Meteorology, Climate Section, unpublished (hourly) cloud data 1988-2018 


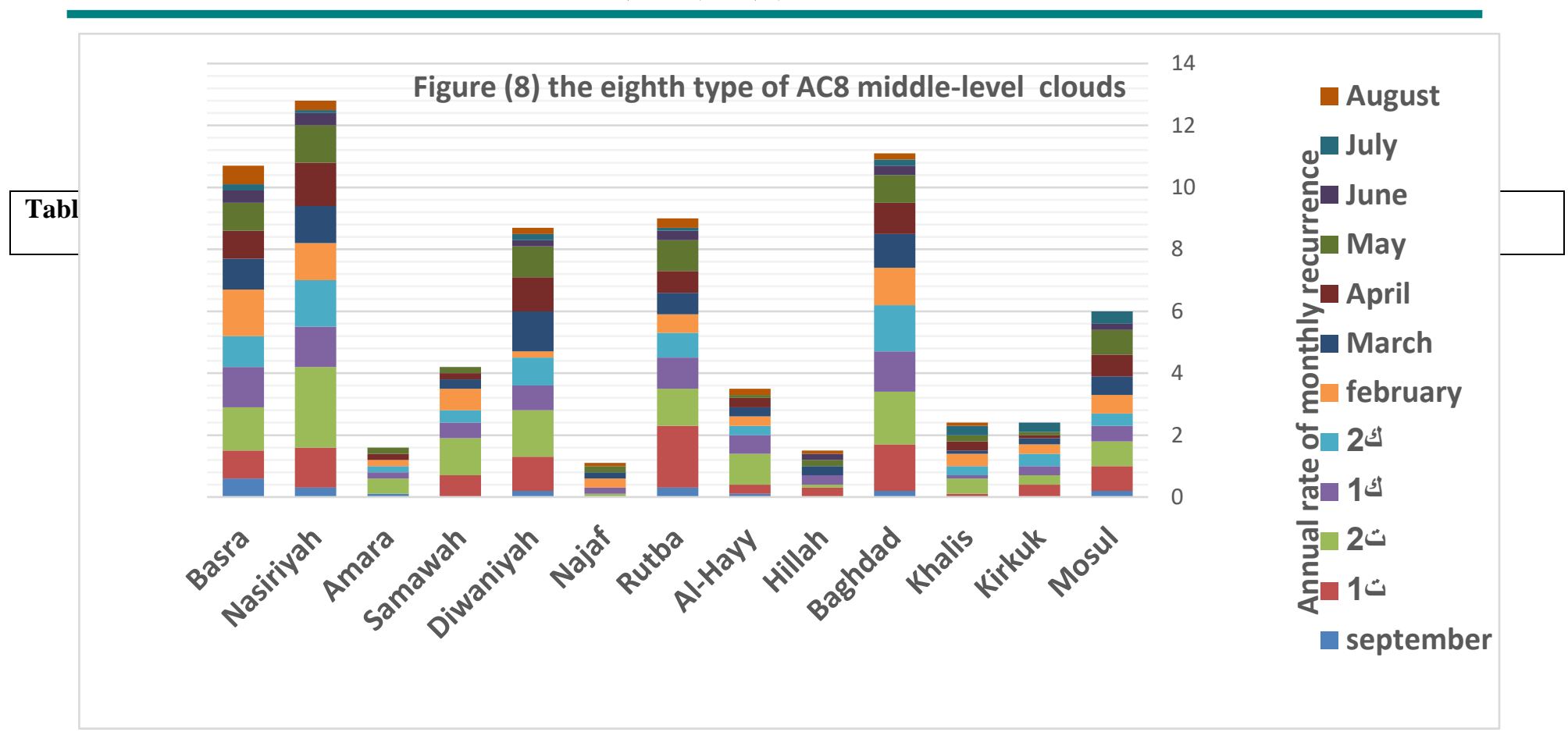

Type 9: Fuzzy Middle-level Altocumulus (AC9)

Following table (10) and figure (9), the ninth type (AC9) is an intermittent middle-level cloud. The stations of the study area did not record duplicates of this type during the period of time as the annual rate of its existence is almost non-existent for all stations except for the two stations Baghdad and Al-Rutba are very few, reaching $(0.2)$ for each station respectively, specifically for March and April only, as these clouds are invisible because of the darkness, fog, dust or flaky dust or any similar phenomenon, or because of a continuous layer of low clouds.
Conclusions

It was concluded from the study that it is possible to classify the region stations according to the nine types of middle-level, higher and less frequent clouds during the study period.

First: The second type is a class scale that recorded the highest value repeatedly for the Al-Hayy station during the study period

Second: The third type is middle-level semitransparent clouds that has repeatedly recorded the highest value for all stations in the study area, except for Al-Hayy station

Third: The ninth type is a disorganized middle-level cloud that was repeatedly recorded the lowest value for all stations in the study area.

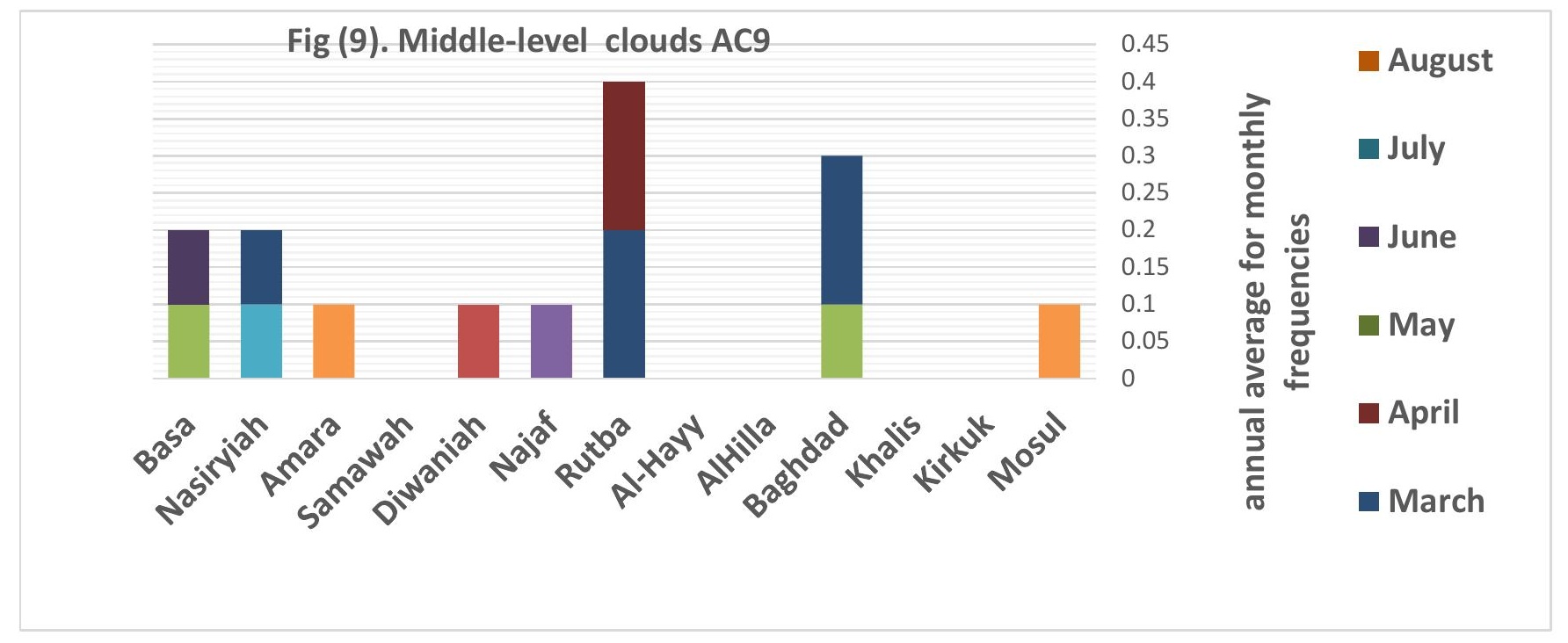




\begin{tabular}{|c|c|c|c|c|c|c|c|c|c|c|c|c|c|}
\hline August & July & June & May & April & March & February & 25 & 1 & ت & ت1 & September & Stations & \\
\hline $\mathbf{0}$ & 0 & 0 & 0 & $\mathbf{0}$ & $\overline{\mathbf{0}}$ & 0.1 & 0 & $\mathbf{0}$ & 0 & $\overline{\mathbf{0}}$ & 0 & Mosul & AC 9 \\
\hline 0 & 0 & $\mathbf{0}$ & $\mathbf{0}$ & $\mathbf{0}$ & $\mathbf{0}$ & $\mathbf{0}$ & $\mathbf{0}$ & $\mathbf{0}$ & $\mathbf{0}$ & 0 & $\mathbf{0}$ & Kirkuk & AC 9 \\
\hline $\mathbf{0}$ & 0 & $\mathbf{0}$ & $\mathbf{0}$ & $\mathbf{0}$ & $\mathbf{0}$ & $\mathbf{0}$ & $\mathbf{0}$ & $\mathbf{0}$ & $\mathbf{0}$ & $\mathbf{0}$ & 0 & Khalis & AC 9 \\
\hline $\mathbf{0}$ & $\mathbf{0}$ & $\mathbf{0}$ & $\mathbf{0}$ & $\mathbf{0}$ & 0.2 & $\mathbf{0}$ & $\mathbf{0}$ & $\overline{\mathbf{0}}$ & 0.1 & $\mathbf{0}$ & $\mathbf{0}$ & Baghdad & AC 9 \\
\hline $\mathbf{0}$ & 0 & $\overline{\mathbf{0}}$ & $\mathbf{0}$ & $\mathbf{0}$ & $\overline{0}$ & 0 & $\mathbf{0}$ & $\mathbf{0}$ & 0 & $\overline{\mathbf{0}}$ & $\overline{\mathbf{0}}$ & Hillah & AC 9 \\
\hline $\mathbf{0}$ & $\overline{\mathbf{0}}$ & $\overline{\mathbf{0}}$ & $\mathbf{0}$ & $\mathbf{0}$ & 0 & 0 & $\mathbf{0}$ & $\mathbf{0}$ & $\mathbf{0}$ & $\overline{\mathbf{0}}$ & $\overline{\mathbf{0}}$ & Al-Hayy & AC 9 \\
\hline 0 & $\mathbf{0}$ & $\mathbf{0}$ & $\mathbf{0}$ & 0.2 & 0.2 & $\mathbf{0}$ & $\mathbf{0}$ & $\mathbf{0}$ & $\mathbf{0}$ & $\mathbf{0}$ & $\mathbf{0}$ & Rutba & AC 9 \\
\hline $\mathbf{0}$ & $\mathbf{0}$ & $\mathbf{0}$ & $\mathbf{0}$ & $\mathbf{0}$ & $\mathbf{0}$ & $\mathbf{0}$ & $\mathbf{0}$ & 0.1 & $\mathbf{0}$ & $\mathbf{0}$ & 0 & Najaf & AC 9 \\
\hline $\mathbf{0}$ & $\mathbf{0}$ & $\mathbf{0}$ & $\mathbf{0}$ & $\mathbf{0}$ & $\mathbf{0}$ & $\mathbf{0}$ & $\mathbf{0}$ & $\mathbf{0}$ & $\overline{\mathbf{0}}$ & 0.1 & $\mathbf{0}$ & Diwaniyah & AC 9 \\
\hline $\mathbf{0}$ & $\mathbf{0}$ & $\mathbf{0}$ & $\mathbf{0}$ & $\mathbf{0}$ & $\mathbf{0}$ & $\mathbf{0}$ & $\mathbf{0}$ & $\mathbf{0}$ & $\mathbf{0}$ & $\mathbf{0}$ & $\mathbf{0}$ & Samawah & AC 9 \\
\hline $\mathbf{0}$ & $\mathbf{0}$ & $\mathbf{0}$ & $\mathbf{0}$ & $\mathbf{0}$ & $\mathbf{0}$ & 0.1 & $\mathbf{0}$ & $\mathbf{0}$ & 0 & $\overline{\mathbf{0}}$ & $\overline{\mathbf{0}}$ & Amara & AC 9 \\
\hline $\mathbf{0}$ & $\overline{0}$ & $\mathbf{0}$ & $\mathbf{0}$ & $\mathbf{0}$ & 0.1 & $\mathbf{0}$ & 0.1 & $\mathbf{0}$ & $\mathbf{0}$ & $\overline{0}$ & $\mathbf{0}$ & Nasiriyah & AC 9 \\
\hline $\mathbf{0}$ & $\mathbf{0}$ & 0.1 & $\mathbf{0}$ & $\mathbf{0}$ & $\mathbf{0}$ & $\mathbf{0}$ & $\mathbf{0}$ & $\mathbf{0}$ & 0.1 & $\mathbf{0}$ & $\mathbf{0}$ & Basra & AC 9 \\
\hline
\end{tabular}

\section{References}

Ali Hassan Musa, (2006(. Encyclopedia of Weather and Climate, ed. 1, Damascus, p. 345

2 Zainab M. Abood and Osama T. Altai, (2018). CALCULATION OFABSORPTION AND EMISSON OF THERMAL RADIATION BY CLOUDS COVER, ARPN Journal of Engineering and Applied Sciences, n24, vol13

Salar Ali Khader Al-Dzi, (2006). Predicting precipitation and using cloud cover data in Iraq, $\mathrm{PhD}$ thesis, University of Baghdad College of Arts, , p.106 Maha Eisa Tawfiq Al-Dalu, (2016). The general trend of cloud cover and its impact on precipitation in Iraq, a study in climate geography, College of Girls Education, University of Baghdad, p.92

Ministry of Transport, Iraqi General Authority for Meteorology and Seismic Monitoring, Climate Section, Clouds data (hourly)
Albert Miller, and Richard.A. Anthes, (1980). Meteorology, Fourth edition, Charles E. Merrill Publishing Company A Bell and Howell company, U.S.A, p. 92

Storm Dunlop translate. Luay Dakhal Allah, the guide to air prediction, i. 1, Kuwait, pp. 40-41

Rahim Idan Fadil Al-Atafi, A climatic study of the recurrence of weather phenomena, clouds, thunderstorms and hail in Iraq, Master Thesis, College of Education, University of Basra, 2010, p. 59

William. L. Donn, Meteorology, Fourth edition, Me Graw-Hill Book company U.S.A. 1975, p. 130

Rahim Idan Fadil, previous source, p.63

Translation of Atlas Clouds, General Authority for Meteorology and Seismic Monitoring, Bulletin No. 198 / World Meteorological Organization publication / First and Second Parts 407, 2012 